\title{
SOCIALIZATION AND TRAINING ACCESS INFORMATION ASEAN COMMUNITY THROUGH NEW MEDIA (INTERNET) BY THE STUDENTS AT SKH. BHAKTI LUHUR CIPUTAT
}

\author{
Denada Faraswacyen L. Gaol ${ }^{1 *}$, Samsinar Samsinar ${ }^{1}$ \\ ${ }^{1}$ Budi Luhur University \\ *df.lgaol@gmail.com
}

\begin{abstract}
Indonesia as the largest country in ASEAN with more than 240 million population in 500 cities and 17 thousand islands, needs various efforts in conducting the 2015 ASEAN Community socialization. Effective socialization cannot only rely on conventional methods as previously carried out by agencies related to socialization through seminars to local governments, universities, schools, and other public organizations, as well as the installation of banners and billboards in public places. To support socialization to be more effective and efficient, it can be helped by using mass media, especially online media. Online media is chosen related to the development of ICT and public connectivity, which generally can access news via the internet or gadgets that are owned. The lag behind the public information about the implementation of the 2015 ASEAN Community in December 2015 cannot be separated from geographical, demographic, and information dissemination that is less equitable from the relevant agencies. This phenomenon is an obstacle in the readiness to implement the ASEAN Community. While the readiness of the government and the public is expected to be able to compete with other ASEAN member countries regarding the era of competition that will be implemented. PKM activities with the theme "Socialization and Training of Access to Information on ASEAN Community through New Media by New Students in Bhakti Luhur Ciputat Special School" in June 2016 were intended to increase their knowledge and insight. This is because many of them do not know the information related to the ASEAN program or agenda, especially those related to free competition by ASEAN Community which has begun this year. Students who have limitations (physical or mental) also have the right to get information related to ASEAN Community so that they are more motivated to equip themselves with knowledge and skills to be independent and compete in the upcoming ASEAN Community era.
\end{abstract}

Keywords: ASEAN, socialization, students

\section{INTRODUCTION}

In implementing or implementing the ASEAN Community 2015, the Indonesian Government must inevitably take strategic steps to succeed in the agenda to a wider audience so as not to miss other ASEAN member countries. One of the government's strategic steps is the 2015 ASEAN Community socialization, which is currently not evenly distributed, only limited to certain circles can be said, the upper middle class. Meanwhile, the general public is not very familiar with it. Never mind getting ready, knowing no. Hopefully, the government can immediately conduct this socialization, no less festive with the 2014 Election campaign complete with its attributes (http://www.tabloiddiplomasi.org/previousisuue/72-December-2009/663-apa-kata-mereka.html).

Many socializations have been carried out by relevant agencies in connection with the ASEAN Community 2015, both through internal socialization in government and private institutions, seminars to educational institutions (schools and colleges), as well as the dissemination of general information through banners, billboards in strategic places to target a broad or public audience. But this cannot be expected to be effective if only by reaching a limited audience and in a short time (http://www.tabloiddiplomasi.org/previous-isuue/76-januari-2010/695-ASEAN community-2015menuju-ASEAN- new-integrative-and-forward-looking.html). There are many other efforts that can be done so that the goals of ASEAN Community 2015 socialization reach as many goals as possible and 
continue to be carried out so that all Indonesian people or at least most of them know that the ASEAN Community 2015 will soon be enacted. In achieving this goal, one that can be done is the ASEAN Community 2015 socialization to all parties by utilizing the mass media. To carry out the socialization of activities, agendas, or programs can be taken through online media as part of the mass media that can reach the public or a wide audience. This is certainly related to the rapid use of ICT development in recent times, and the ease of accessing information through online media by anyone who has connectivity to information online.

The need for ASEAN Community 2015 socialization is that considering that geographically and demographically Indonesia is the largest and most populous country compared to other ASEAN member countries. For this reason, extra effort is needed in introducing or socializing the 2015 ASEAN Community agenda to the Indonesian public. Through socialization activities, it is expected that all parties can prepare themselves and their abilities in the face of competition in the 2015 ASEAN Community era. With Indonesia's geographical and demographic conditions, it can be both a strength and a weakness in the 2015 ASEAN Community era. A large area (geographical) if utilized by exploring and optimizing existing resources can be economically beneficial for the community and government. A large demographic (population) condition can be used as a source of productive labor from the availability of many human resources for profitable production activities. But if the geographical and demographic conditions cannot be used as strengths, then what happens is the opposite. This can be a weakness because it can be a source of problems due to the inability to compete in the free era when the ASEAN Community 2015 was enacted.

ASEAN Community 2015 socialization through online media can target the public from diverse backgrounds, especially those that have not been reached through government socialization. This is reflected in what is carried out by the Ministry of Education and Culture through the ASEAN goes to campus program which carries the theme "Toward ASEAN Community 2015: ASEAN Goes to Campus" held in three cities, namely Solo, Medan, and Malang. (http://kebudayaan.kemdikbud.go.id/ditindb/2014/04/30/sosialisasi-toward-ASEAN-community-

2015-ASEAN-goes-to-campus- at-universitas-sebelas-maret-solo/) . Furthermore, what was carried out by the Indonesian Ministry of Foreign Affairs through socialization by conducting roadshows to various regions, universities, and schools (ASEAN Community Correctional 2015: Preparing Gorontalo for Entering the 2015 ASEAN Community in http://www.kemlu.go.id/Pages/ NewsKemlu.aspx? IDP = $379 \& 1=\mathrm{id})$.

Indonesia as the largest country in ASEAN with more than 240 million population spread over 500 cities and 17 thousand islands, needs various efforts to disseminate the 2015 ASEAN Community. Effective socialization cannot only rely on conventional methods as previously carried out by agencies related to socialization through seminars to local governments, universities, schools, and other public organizations, as well as the installation of banners and billboards in public places. To support socialization to be more effective and efficient, it can be helped by using mass media, especially online media. Online media is chosen related to the development of ICT and public connectivity, which generally can access news via the internet or gadgets that are owned. The lag behind the public information about the implementation of the 2015 ASEAN Community in December 2015 cannot be separated from geographical, demographic, and information dissemination that is less equitable from the relevant agencies. This phenomenon is an obstacle in the readiness to face the 2015 ASEAN Community which has been implemented since the beginning of January 2016. While the readiness of the government and the public is expected to be able to compete with other ASEAN member countries regarding the era of competition that will be enacted. Based on this description, Budi Luhur University's FISIP PKM Implementation Team intends to hold PKM activities with the theme "Socialization and Training on Access to ASEAN Community Information through New Media by Students in Bhakti Luhur Ciputat Special School" in June 2016. Selection of this place based on the cooperation framework contained in the Letter of Agreement between Budi Luhur University FISIP and Bhakti Luhur Ciputat Special School which is valid for two semesters, namely the 2015/2016 and Even 2015/2016 Semester Odd Semester. Therefore, PKM activities in this semester are a follow-up of the first phase of PKM that has been implemented in the last 2015/2016 Semester.

The choice of theme is based on the lack of information related to the implementation of the ASEAN Community obtained by students at the Bhakti Luhur Ciputat Special School. Many of them 
do not know the information related to the ASEAN program or agenda, especially those related to free competition by ASEAN Community which has begun this year. PKM activities are planned to be filled with two main activities, namely socialization with presentation methods about ASEAN and its agenda of activities and training on access to information related to ASEAN Community through new media (internet). The PKM Implementing Team assesses that students who have limitations (physical or mental) also have the right to get information related to ASEAN Community so that they are more motivated to equip themselves with knowledge and skills to be independent and compete in the upcoming ASEAN Community era. Bhakti Luhur Ciputat Special School as an educational institution has carried out its role in teaching and educating students in terms of knowledge and skills. For this reason, the PKM Implementation Team intends to hold activities as a form of support for the Bhakti Luhur Special School and at the same time implementing one of the Tridharma Lecturers. PKM preparation is carried out since April 2016 and is planned to take place at the end of May 2016 with consideration before the UAS schedule of students at the Bhakti Luhur Special School.

\section{METHOD}

The methods used in the implementation of this activity are:

\section{Observation}

The Implementation Team of the FISIP Community Service Program (PKM) Budi Luhur University made observations to the Bhakti Luhur Ciputat Special School to find out the description of the conditions of the students and caregivers. Observations were made in several visits, by observing learning activities inside and outside the classroom, the activities of students living in dormitories, such as making tempeh, gardening, and sports to train motors. This observation has been carried out since the 2015/2016 Semester since this PKM activity is a series of semesters. Interview The team held a meeting and interview with the Principal, Sr. Cicilia Rukiyah, S.Pd., teachers represented by Ms. Theresia Ismiyati, S.Pd, and Mrs. Emmyrita Dalmiati, S.Pd, employees represented by Ms. Bernadetta Sulastri, and caregivers or companions of students, Theresia Agatha Avila, and Stefani Wahyuningsih. Furthermore, the Bhakti Luhur Special School submits an Application Letter to the PKM Implementation Team to carry out activities according to the agreed theme. Furthermore, the Teaching Team coordinated with the school in relation to the schedule and active material.

\section{Interaction/communication}

Interaction with students is done through verbal communication through the implementing coordinator in the field, namely Ms. Emmyrita Dalmiati, S.Pd. On the day of the activity, students present in one of the classrooms that have been prepared in advance. They are accompanied by several students as guides if there are difficulties operating the laptop as a means of accessing information during the activity.

\section{DISCUSSION}

\section{Preparation Phase}

The preparation stage is carried out to plan all the needs that will be used during the implementation of the activity. This stage consists of:

a. Preparation of Team Members and Division of Tasks

The Implementation Team consists of Chairperson, Denada Faraswacyen L. Gaol, M.Si from FISIP and Samsinar, M.Kom from FTI. Some students from FIKOM and FISIP are Maulana Qodrat (1271501320), Banu Dwiputra Rahman (1270500546), and Rudolof D.T. Rene'L (1242500138). The students are given the task of assisting students in operating laptops and helping if there are obstacles during the training process.

b. Correspondence and communication with SKh. Bhakti Luhur through the Principal, Sr. Cicilia Rukiyah, S.Pd, Mrs. Theresia Ismiyati, S.Pd., and Mrs. Emmyrita Dalmiati, S.Pd to design preparations to the implementation of activities at the agreed time based on the willingness of the Executing Team and SKh students. Bhakti Luhur. 


\section{c. Props}

The PKM Implementation Team prepares equipment and equipment consisting of Notebooks, LCD Projectors, extension cables, banners, internet modems, and DSLR cameras. The Chairperson of the Implementation Team coordinated with Ms. Sulastri from SKh. Bhakti Luhur in preparing related rooms and supporting facilities.

\section{Implementation Phase}

On Tuesday, June 21, 2016, at 08.00 WIB, the Implementation Team departed from Budi Luhur University to SKh. Bhakti Luhur to start the activity at 9.30 WIB. The team departed with equipment and supplies. After arriving at SKh. Bhakti Luhur, the team leader met with the teacher in charge of the activity, namely Ms. Emmyrita Dalmiati, S.Pd to coordinate the activities on that day. The students are ready in one of the 2 nd floor classrooms arranged in the form of $U$ in order to facilitate the assistance of each child The team prepared an LCD Projector, distributed notebooks to each student table, activated an internet connection, and a Broadcasting Journalism student, Banu Dwiputra Rahman, standby with DSLR cameras to document activities while occasionally accompanying and giving explanations if there were questions about notebooks and ASEAN.

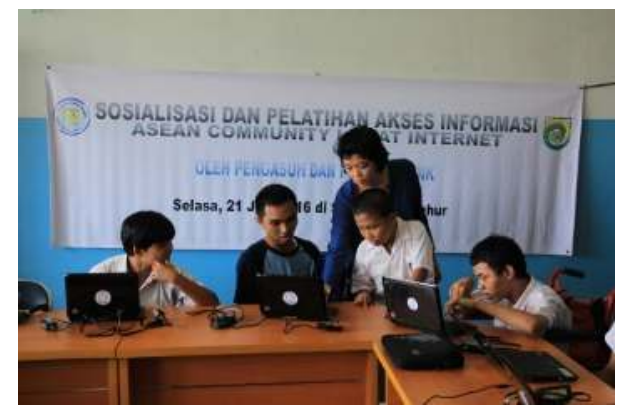

Figure 1. The Chair of PKM is Explaining How to Use the Notebook to Students

The lecturer team gave an explanation about ASEAN starting from general information related to ASEAN such as member countries, flags, geographical location, the potential of each country. Students are also taught to access information (browsing) from the internet related to information about ASEAN. Information acquisition is not only through browsing but also using globe tools to show the geographical position/position of ASEAN countries located side by side in one region.

The students are also taught to create their own e-mail account and insert photos as the identity of their e-mail account. The students were very enthusiastic when they were taught to create an e-mail account. The training model provided is not only in the form of teaching but also in an active dialogical manner because there is a question and answer session between the lecturer team and the students, for example playing blind map games. After explaining about ASEAN, the team of lecturers showed a blind map of the projector and then asked the name of the country and capital.

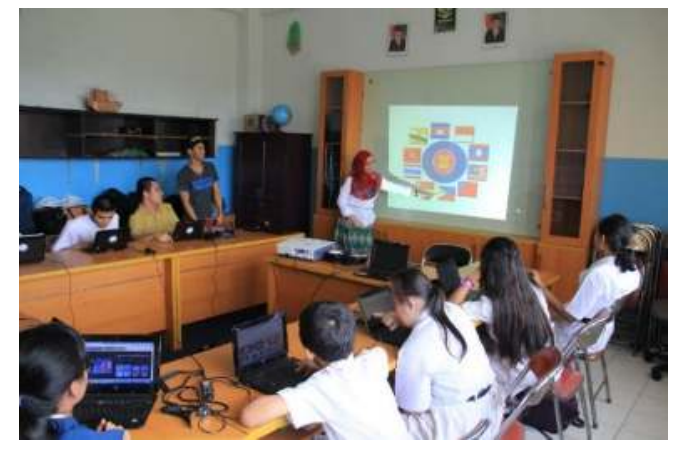

Figure 2. The instructor is explaining ASEAN countries 
The team of lecturers gave explanations about ASEAN member countries through visual images to make it more attractive to students. This method is used because images with bright colors are easier to capture and understand than using only long descriptions of explanations. They are easier to recognize and name the country when there are questions related to the flag of one country than continue to explain the geographical location of these neighboring countries or in one region.

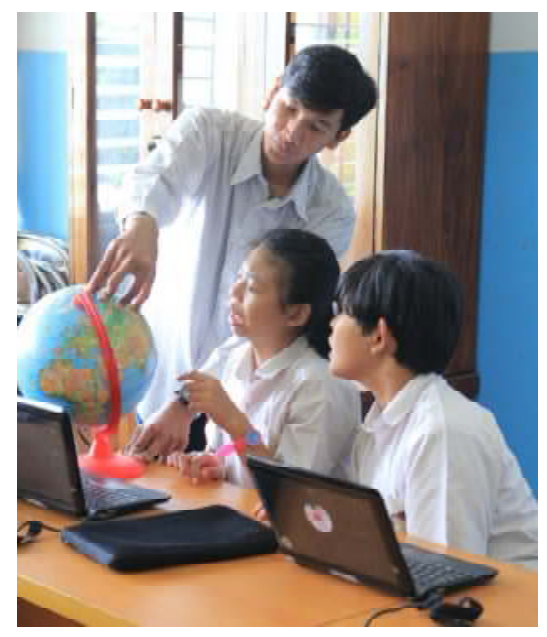

Figure 3. Companion Student Explains Geographical Location of ASEAN Countries

Explanation of the geographical location is assisted by showing the location or position of each country on the globe (globe). With this method, they are more motivated and motivated and have a dream to travel around the world because they see how many countries are side by side and attract students' interest or curiosity. Many questions were asked regarding the neighboring countries of Indonesia, such as the language used, the tourist destinations they have, the season that goes on, and other things that interest them.

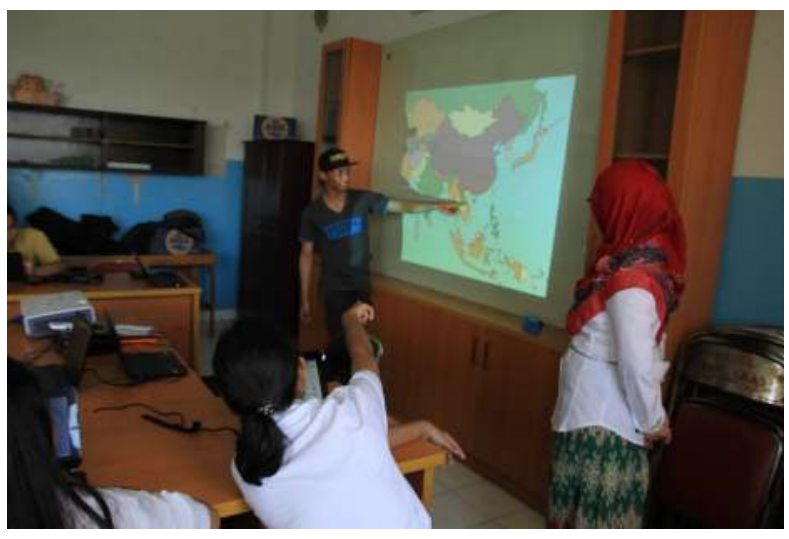

Figure 4. Companion Students are Explaining ASEAN Countries

Companion students also provide explanations to students through map images as additional information regarding the geographical location of ASEAN countries. They explained in simple language that it was easy for students to understand and had a persuasive approach so they could focus on listening to the material being explained. Each companion student carries out his duties according to the schedule that has been arranged beforehand so that all students get the maximum portion of the explanation and increase their knowledge. 


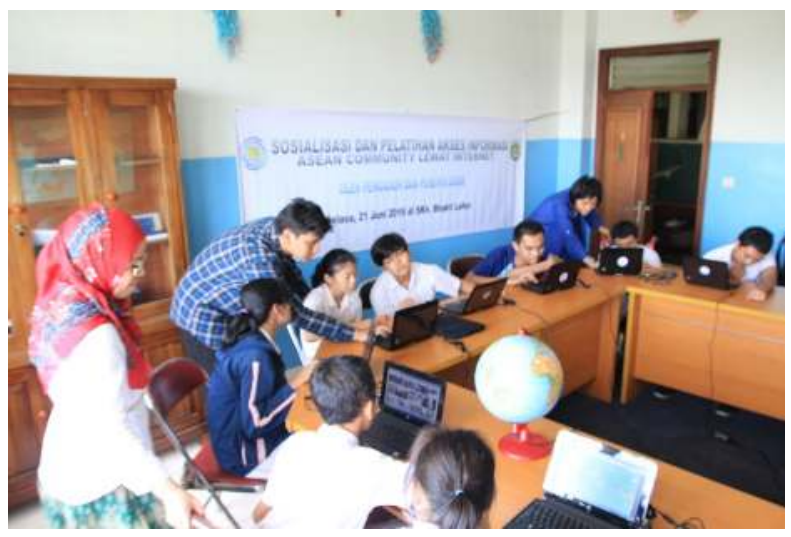

Figure 5. PKM Implementation Team Accompanying Students to Work Out Exercises

After giving material about how to create an e-mail account, access information via the internet, and explain about ASEAN, then to find out the level of understanding and knowledge of students are given training questions related to the three materials. The results show that for the category of children with special needs they are quite good in terms of their level of understanding because they easily receive new information through explanations in simple language to be easily understood by them.

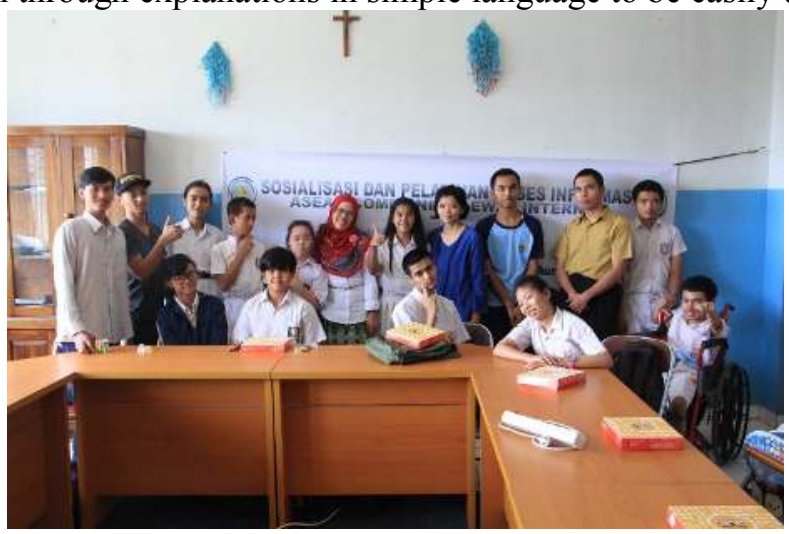

Figure 6. PKM Team Photographs Together with SKh Students. Bhakti Luhur

PKM activities end after lunch according to the schedule agreed by the PKM Team and SKh Teachers. Bhakti Luhur. Some students returned to the dormitory and others returned to their homes with their parents picked up. These students are happy with the PKM activities that have been carried out twice in January and June 2016. They expressed their gratitude and hope that similar activities could be carried out again in the coming semesters. The PKM team was also happy with the cooperation and enthusiastic welcome from SKh. Bhakti Luhur because the activities take place smoothly and according to the original plan marked by the achievement of the target participants and the appropriate implementation time.

\section{Reporting Step}

At this step, PKM Implementation Team documents all stages of the activity in the form of writing and photographs of activities that will be prepared in the form of reports. The reporting phase contains an evaluation of the implementation of activities, budget realization, printing certificates, and submitting reports to the Directorate of Research and Community Service (DRPM) of Budi Luhur University. 


\section{Implementing Instrument}

The instruments for implementing community service programs include activity schedules, implementation arrangements, supporting equipment, target participants and topics.

a. Schedule of activities:

The socialization and training activities were carried out on June 21, 2016.

b. Organizing Structure of Community Service

Chairman: Denada Faraswacyen L. Gaol, M.Sc (080138)

Member: Samsinar, M.Kom (070028)

Budi Luhur University students

c. Ancillary equipment

Supporting equipment for carrying out Community Service activities are Notebook, LCD Projector, extension cable, banner, and camera.

d. Participants

Participants are 20 people

e. Topic The topic of Community Service is ASEAN Community Information Access and Training Access through New Media by Students in Bhakti Luhur Ciputat Special School.

\section{CONCLUSION}

ASEAN Community is an ASEAN agenda that is mutually agreed upon by all member countries and began to be implemented since January 2016. This joint agenda can be implemented well if all relevant information reaches the public or the public. In conveying information related to the ASEAN Community starting from preparation to implementation carried out by various parties such as the central and regional governments, educational institutions, and others. The socialization that has been carried out so far, whether by government agencies or educational institutions, is still felt to be less accessible to all levels of society. Therefore, educational institutions deliver socialization by conventional means, namely visiting the locations of schools that are considered to be less affordable or missed from the socialization activities that have been carried out so far.

One educational institution that needs socialization is the Bhakti Luhur Special School. This school teaches and educates children with special needs starting from the level of education equivalent to elementary, middle and high school. The students in this school are divided into two categories, namely participants who live in the dormitory and students who return to their homes. By looking at the condition of these students, the Budi Luhur University PKM FISIP Implementation Team targets to conduct socialization and training in accessing information related to the ASEAN Community through new media. This activity aims to provide information about preparations that should be carried out by the community as citizens in entering the competition in the current ASEAN Community era.

The students are given an understanding of the importance of having the skills and skills to be able to be cheerful with other ASEAN citizens to have selling points and be able to compete in the future. The students belonging to the age group of children and adolescents are given training in accessing the information they need such as the ASEAN Community. They were also taught to create their own e-mail accounts so that they could utilize technology tools to support the advancement of ICT as a modern communication tool.

\section{REFERENCES}

http://www.tabloiddiplomasi.org/previous-isuue/72-December-2009/663-apa-kata-mereka.html accessed on April 20, 2016, at 09.00 WIB.

http://www.tabloiddiplomasi.org/previous-isuue/76-januari-2010/695-ASEAN-community-2015menuju-ASEAN-baru-yang-integratif-dan-berwawasan-ke depan.html accessed on April 20, 2016, at 09.30 WIB. 
http://kebudayaan.kemdikbud.go.id/ditindb/2014/04/30/sosialisasi-toward-ASEAN-community-2015ASEAN-goes-to-campus- at-universitas-sebelas-maret-solo/ accessed at 25 April 2016 at 09.00 WIB.

http://www.kemlu.go.id/Pages/NewsKemlu.aspx?IDP=379\&l=id accessed on April 25, 2016, at 09.30 WIB. Budi Luhur University PKM Implementation Guide Booklet Book Overview of Bhakti Luhur Ciputat Foundation 